\title{
Korelasi Implementasi Model Poe Berbasis Inquiri-Humanistik dengan Higher Order Thinking Skill Level I Decision Making pada Praktikum Fisika Dasar
}

\author{
Umi Pratiwi ${ }^{1}$ dan Nurhidayati ${ }^{2}$ \\ ${ }^{1)}$ Pendidikan Fisika, Universitas Muhammadiyah Purworejo \\ ${ }^{2)}$ Pendidikan Fisika, Universitas Muhammadiyah Purworejo \\ Email: umipratiwi@umpwr.ac.id
}

\begin{abstract}
Curriculum 2013 as a curriculum that emphasizes the three domains of learning strongly supports the ability to solve problems. One of the capabilities that must be prepared in this century is the ability of high-level thinking is an important ability as part of the process of problem solving. This study aims to determine the ability of high-level thinking at Level I decision-making stage before entering the stage of problem solving, that is how the correlation of the application of InquiriHumanistic POE model (variable $x$ ) to the thinking ability of high level I in the decision making stage (variable II). This study uses the application of inquiry-humanistic POE model as a solution in solving the problems faced by physics education students. The subjects of the study used one group of subjects without any comparison, namely the second semester students of physics education courses in the Physics Basic lab course. This research is a pre experimental study of pretest-posttest one-group design supported by qualitative-descriptive approach. The research data is conducted using observation and test of high-order thinking ability (pretest end posttest). The results showed that the application of inquire-humanistic POE model correlated $0.307 \%$ to the ability of high level thinking level I in the decision making stage. It is expected that the next level can be measured significantly with the implementation of inquiry-humanistic POE model
\end{abstract}

Keywords : POE inquiri-humanistik, HOT level I, Decision making

This is an open access article distributed under the Creative Commons 4.0 Attribution License, which permits unrestricted use, distribution, and reproduction in any medium, provided the original work is properly cited $\odot 2018$ by author and Universitas Negeri Padang.

\section{PENDAHULUAN}

Kurikulum 2013 sebagi pelopor pen didikan karekter menjadi pendongkrak pendidik an di Indonesia. Pendidikan sebagai rancangan masa depan bangsa harus dikelola dengan serius dan terprogram. Siswa ataupun mahasiswa sebagai obyek pendidikan harus didampingi guru yang visioner dan solutif dalam menyelesai kan berbagai permasalahan yang dihadapi oleh mereka apalagi mahasiswa calon guru. Guru sebagai pengambil kebijakan pendidikan harus bisa menjalankan sistem pembelajaran yang sukses mengantarkan siswanya kearah lebih baik. Abad 21 menuntut semua segi pendidikan harus dapat mempersiapkan diri dan terlepas dari permasalahan yang dihadapi saat ini seiring dengan perkembangan teknologi yaitu tantang masa depan dalam kemampuan berpikir sebagai bekal persaingan didunia kerja. Kemampuan berpikir siswa dan mahasiswa pada umumnya terutama pada sekolah-sekolah dengan kualitas menengah masih memiliki kemamapuan ber pikir yang rendah. Pada era persaingan bebas didunia memerlukan kemampuan berpikir tingkat tinggi dalam proses persiapan SDM untuk menghadapinya. Demikian halnya dengan pembelajaran Ilmu Pengetahuan Alam (IPA) khususnya pembelajaran Fisika yang menuntut keterlibatan mahasiswa secara aktif dan memerlukan kemampuan berpikir tingkat dalam menyelesaikan permasalahan yang di hadapi.

Hakikat IPA adalah ilmu pengetahuan yang mempelajari gelala-gejala melalui serang kaian proses yang dikenal dengan proses ilmiah yang dibangun atas dasar sikap ilmiah dan hasilnya terwujud sebagai produk ilmiah yang tersusun atas tiga komponen terpenting berupa konsep, prisip dan teori yang berlaku secara universal (Muzari, dkk, 2016). Menurut Fowler (dalam Pratiwi dan Nurhidyati, 2017) menyata kan bahwa IPA/fisika memuat suatu pengetahu an teoritis yang diperoleh/disusun dengan cara yang khas dan khusus, yaitu melakukan observasi eksperimentasi, penyimpulan, pe nyusunan teori, eksperimentasi, dan demikian seterusnya kait-mengkait antara cara yang satu dengan cara yang lain. 
Penelitian ini bertujuan untuk mendidik calon guru fisika dalam skill peningkatan $\mathrm{Ke}$ mampuan Berpikir Tingkat Tinggi (Higher Order Thinking Skill) pada level I yang merupakan level tertinggi HOT yaitu ke mampuan Strategies thinking. Kemampuan Strategies thinking terdiri dari tiga kemampuan dasar, yaitu kemampuan mengkonsep (Concep tualizing),membuat tujuan (Decision making), dan pemecahan masalah (Problem solving) (Passey, 2009; LTAAP,2000; Pratiwi,2015; Pratiwi dan Nurhidayati,2017). Kemampuan ini dicapai menggunakan model pembelajaran POE (Predict, Observe, dan Explain) berbasis Inquiri-Humanisme. Kemampuan berpikir tingkat tinggi pada level I berfokus pada kemampuan decision making yaitu kemampuan dalam menjelaskan tujuan apa yang akan dilakukan dan memberikan solusi atau pendekat an sementara terhadap permasalahan yang di hadapinya. Tahapan ini merupakan tahapan persiapan sebelum memasuki tahapan lebih tinggi lagi yaitu problem solving.

Model pembelajaran POE (PredictObserve-Explain) merupakan suatu model yang efisien untuk menciptakan diskusi para maha siswa calon guru fisika mengenai konsep ilmu pengetahuan. Model pembelajaran POE me libatkan mahasiswa dalam meramalkan suatu fenomena, melakukan observasi melalui demonstrasi atau eksperimen, dan akhirnya menjelaskan hasil demonstrasi dan ramalan mereka sebelumnya (Indrawati dan Setiawan 2009). Kemampuan POE (prediksi, observasi, eksplanasi) dapat menyelidiki gagasan maha siswa dan cara mereka dalam menerapkan pengetahuan pada keadaan yang sebenarnya (praktikum) untuk diterapkan dalam proses belajar dan pembelajaranya ketika menjadi seorang guru sebenarnya.

Inkuiri integrasikan dengan nuansa humanistik, sehingga Model POE ini bernuansa inquiri-Humanisme dengan maksud membangkit kan dan membentuk karakteristik sikap ilmiah untuk menyelidiki atau meneliti tentang fenomena yang terjadi dan menjadi pendidik humanistik yang menekankan pada kebutuhan anak atau child-centered peserta didik/ mahasiswa (Pratiwi dan Nurhidayati, 2017). Penelitian ini dilakukan pada mahasiswa calon guru fisika II matakuliah Praktikum Fisika Dasar program studi Pendidikan Fisika UM Purworejo. Diharapkan dengan implemen tasi model POE ini dapat menghasilkan kemampuan mahasiswa dalam menyelesaikan permasalahan yang dihadapi dalam kehidupan nya.

\section{METODE PENELITIAN}

Penelitian ini adalah penelitian eksperimen dengan pendekatan penelitian kuantitatif yang didukung oleh pendekatan kualitatif-deskripsi, yaitu penelitian Pre experimental pretestposttest one group design (arikunto, 2002; Pratiwi dan Nurhidayati, 2017).

Penelitian ini untuk mengetahui seberapa besar korelasi atau hubungan antara imple mentasi model POE berbasis Inkuiri-Humanistik dengan kemampuan berpikir tingkat tinggi atau HOT level I dan mendapatkan gambaran kemampuan berpikir tingkat tinggi level I pada praktikum fisika dasar.

Varibel dalam penelitian ini yaitu variabel bebas (independent variable) adalah (Sugiyono, 2009; Mundir, 2013) (X) yaitu implementasi model POE berbasis Inquiri-Humanistik. Sedangkan Variabel terikat (Y) adalah ke mampuan HOT level I. Indikator masing-masing variabel diperlukan dalam proses pengambilan data observasi dan tes. Model POE terdiri dari tiga tahapan, yaitu Predict, Observe, dan Explain. Masing-masing tahapn POE ter integrasi kedalam pembelajaran inquiri. Imple mentasi ini bernuansa humanistik artinya mahasiswa diberi kebebasan untuk memilih materi praktikum sesuai kemampuan. Ke mampuan berpikir tingkat tinggi level I Thingking Strategies mempunyai tiga tahapan, yaitu kemampuan mengkonsep, kemampuan membuat kesimpulan, dan kemampuan memecahkan masalah. Kisi-kisi umum indikator variabel $Y$ dan $X$ dapat dilihat di bawah ini.

a. Model POE Integrasi dengan Inkuiri sebagai variabel $X$

1) Tahap I "Predict"

Tahap I Inkuiri Tune In, dengan indikator: Membuat Hipotesis $\rightarrow$ Prediksi hasil paraktikum (Soal No. 4 HOT)

2) Tahap II "Observe"

Tahap II Inkuiri Focus Question dan Tahap III Inkuiri Prepare Inquiri, dengan indikator: Mahasiswa melakukan eksperimen/praktikum dengan aktif sesuai dengan prosedur (Observasi) dengan penilaian sebagai berikut:

a) Nilai $4 \rightarrow$ Melakukan eksperimen dengan kepahaman 
b) Nilai $3 \rightarrow$ Melakukan ekperimen dengan bertanya $1 \mathrm{x}$ terlebih dahulu

c) Nilai $2 \rightarrow$ Melakukan eksperimen dengan kebingungan

d) Nilai $1 \rightarrow$ Melakukan ekperimen banyak bertanya dan memperlihatkan ketidakpahaman.

3) Tahap III "Explain"

Tahap IV Inkuiri Gather Evidence dan Tahap V Inkuiri Communicate Finding dengan indikator:

- Berdiskusi dalam melakukan eksperimen, penilaian dengan observasi, dengan ketentuan sebagai berikut:
a. Nilai $4 \rightarrow$ Aktif bertanya $3 x$ dan aktif berdiskusi
b. Nilai $3 \rightarrow$ Aktif bertanya $2 x$ dan aktif berdiskusi
c. Nilai $2 \rightarrow$ Aktif bertanya $1 \mathrm{x}$ dan aktif berdiskusi
d. Nilai $1 \rightarrow$ Tidak aktif bertanya dan berdiskusi

- Mahasiswa mampu membandingkan antara hasil ekperimen dengan teori $\rightarrow$ dalam laporan

- Melakukan presentasi berkaitan dengan eksperimen, dengan penilaian sebagai berikut:
a. Nilai $4 \rightarrow$ Mempresentasikan dengan baik dan lengkap
b. Nilai $3 \rightarrow$ Mempresentasikan dengan baik dan tidak berurutan/lengkap

c. Nilai $2 \rightarrow$ mempresentasikan kurang baik dan sedikit lengkap

d. Nilai $1 \rightarrow$ Memepresentasikan tidak baik dan kurang lengkap

- Memberikan kesimpulan tujuan dan dibandingkan dengan teori
a. Nilai $4 \rightarrow$ Kesimpulan sesuai
b. Nilai $3 \rightarrow$ Kesimpulan sesuai tujuan tanpa dibandingkan dengan teori
c. Nilai $2 \rightarrow$ Kesimpulan tidak sesuai dengan tujuan
d. Nilai $1 \rightarrow$ Tidak ada kesimpulan

b. Indikator HOT level I "thinking strategic"

Tahap I Conceptualizing, dengan indikator: (1). Mengidentikasikan permasalahan $\rightarrow$ Soal HOT No. 2

a. Nilai $4 \rightarrow$ mengidentifikasikan masalah dengan lengkap b. Nilai $3 \rightarrow$ Mengidentifikasi lebih dari dua variabel

c. Nilai $2 \rightarrow$ mengidentifikasikan 1 variabel

d. Nilai $1 \rightarrow$ Tidak dapat mengidentifikasi kan masalah sama sekali

Tahap II Decision Making, dengan indikator, (2). Menjelaskan tujuan praktikum yang akan dilakukan $\rightarrow$ Soal HOT No. 1

a. Nilai $4 \rightarrow$ Mampu menjelaskan prosedur praktikum dan tujuannya dengan lengkap dan benar

b. Nilai $3 \rightarrow$ Mampu menjelaskan prosedur dan tujuan praktikum mendekati lengkap

c. Nilai $2 \rightarrow$ Mampu menjelaskan prosedur dan tujuan hanya sedikit

d. Nilai $1 \rightarrow$ Tidak Mampu menjelaskan prosedur praktikum dan tujuannya sama sekali

(3). Membuat solusi permasalahan/ pendekatan solusi $\rightarrow$ Soal HOT No. 2

a. Nilai $4 \rightarrow$ Mampu menjelaskan data yang akan diperoleh dan perhitungan nya dengan lengkap

b. Nilai $3 \rightarrow$ Mampu menjelaskan data yang akan diperoleh dan penyelesaian nya/persamaan tidak lengkap

c. Nilai $2 \rightarrow$ Mampu menjelaskan salah satu data yang akan diperoleh atau persamaannya tetapi tidak lengkap

d. Nilai $1 \rightarrow$ Tidak dapat menjelaskan data yang akan diperoleh dan perhitungan nya

Tahap III Problem Solving dengan indikator: (4). Mampu memahami dan menjelaskan permasalahan $\rightarrow$ Soal HOT No. 3

a. Nilai $4 \rightarrow$ mampu menjelaskan pokok permasalahan dngan lengkap

b. Nilai $3 \rightarrow$ Mampu menjelaskan namun kurang lengkap

c. Nilai $2 \rightarrow$ Mampu menjelaskan hanya sedikit

d. Nilai $1 \rightarrow$ Tidak dapat menjelaskan masalah sama sekali

(5). Membuat solusi yang dipilih $\rightarrow$ Soal HOT No. 5 
a. Nilai $4 \rightarrow$ Mampu menyelesaikan dengan benar

b. Nilai $3 \rightarrow$ Mengidentifikasi lebih dari dua variabel dan menyelesaikan walaupun tidak sempurna

c. Nilai $2 \rightarrow$ mengidentifikasikan 1 variabel

d. Nilai $1 \rightarrow$ Tidak mampu menyelesaikan sama sekali

(6). Evalusai $\rightarrow$ sesuai dengan indikator ke-

6 Model POE-Inkuiri bersumber dari laporan

a. Nilai $4 \rightarrow$ pembahasan sesuai tujuan, teori dan hasil praktikum dan membahas dengan lengkap

b. Nilai $3 \rightarrow$ Pembahasan sesuai dengan teori dan tujuan tetapi tidak ada kolerasi anatara hasil dengan teori

c. Nilai $2 \rightarrow$ Pembahasan sedikit sesuai dengan tujuan dan teori

d. Nilai $1 \rightarrow$ Pembahasan tidak sesuai dengan tujuan dan teori

Teknik analisis data sebagai berikut:

a. Uji Normalitas

Teknik analisis data menggunakan uji normalitas menggunakan uji Kolmogorovsminov dan Shapiro wilk (Prayitno, 2009). Sebaran hasil uji normalitas normal atau tidak menggunakan kaidah yaitu: jika $\mathrm{p}>0.05$ maka sebaran dikatakan normal. Namun sebaliknya jika uji normalitas sebaran menunjuk kan $\mathrm{p}<0.05$ maka sebaran

dikatakan tidak normal (Azwar, 2012), Analisis data kualitatif diperoleh dari hasil observasi selama pelaksanaan penelitian dari awal praktikum sampai akhir praktikum.

b. Analisis Data Kualitatif

Analisis data kualitatif diperoleh dari hasil observasi selama pelaksanaan penelitian dari awal praktikum sampai akhir praktikum.

c. Analisis Data Kuantitatif

Analisis data kuantitatif berasal dari lembar tes tahapan model POE berbasis InkuiriHumanistik dilakukan dengan cara men distribusikan skor dan menghitung rentang penilaian pada skala kemampuan HOT level I yang disesuaikan dengan banyaknya indikator penilaian menggunakan skala linkert (Sudirman, 2012). Pengujian efektifitas mplementasi model POE berbasis InkuiriHumanistik pada penelitian ini menggunakan teknik analisis parametrik komparasi T-test of
Related atau uji $\mathrm{T}$ berkorelasi (uji banding berkorelasi) dihitung dengan SPSS 16.

\section{HASIL PENELITIAN}

Penelitian untuk mengetahui kemampuan berpikir tingkat tinggi mengunakan penerapan model POE bernuansa inquiri-humanistik fisika pada matakuliah praktikum fisika dasar telah selesai dilaksanakan. Model POE sebagai predict, observe, dan explain berkolaborasi dengan lima tahaapan inkuiri yaitu tune in, focus question, prepare inquiri, gather evidence, dan communicate finding.

Kedua model pembelajaran tersebut di implementasikan dalam proses percobaan sebagai treatment dengan model POE ber kolaborasi dengan inkuiri. Sedangkan prinsip humanistik terdapat pada keberagaman materi praktikum antara kelompok satu dengan kelompok lainya, bahwa peserta praktikum dalam hal ini mahasiswa semester II pendidikan fisika diberi kesempatan untuk mempersiapkan diri sebaik-baiknya dalam pemahaman materi praktikum sebagai persiapan proses pelaksanaan praktikum dengan khusus mempelajari satu materi yang menjadi fokus tugasnya saja (Pratiwi dan Nurhidayati, 2017).

Pelaksanaan penelitian menggunakan materi bervariasi sebagai penerapan prinsip "Humanistik" dalam proses pembelajaran. Terdapat 5 materi praktikum untuk masingmasing kelompok dengan menerapkan prinsip humanistik. Hasil treatment tiga proses tersebut dihasilkan data penelitian hasil pretest sebagai gambaran awal kemampuan mahasiswa, hasil kemampuan implementasi POE inkuiri dan HOT level I (hasil konversi range 100), dan hasil posttest yang diperoleh dari penilaian laporan praktikum yang dapat dilihat keterangan di bawah ini yang menunjukkan nilai rata-rata variabel $X$ dan $Y$ juga pre test dan post test.

Tabel 1. Rekapitulasi Hasil Pre Test, Implementasi POE-Inkuiri, Kemampuan HOT dan Post Test Per Mahasiswa

\begin{tabular}{|c|c|c|}
\hline No. & Komponen & Rata-Rata \\
\hline 1. & Pre Test & 74,65 \\
\hline 2. & POE-Inkuiri & 76,24 \\
\hline 3. & HOT & 58,26 \\
\hline 4. & Post Test & 80,25 \\
\hline & Rata-Rata Total & $\mathbf{7 2 , 3 5}$ \\
\hline
\end{tabular}

Proses pelaksanaan penelitian dan pengambilan data dibagi dalam tiga proses, 
yaitu pretest dengan menerapkan penilaian soal HOT, implementasi POE inkuiri sebagai proses treatment, dan posttest sebagai proses evaluasi. Tabel 1 di atas menunjukkan nilai rata-rata mahasiswa pada lima materi percobaan. Masingmasing kelompok terdiri dari lima mahasiswa dengan materi yang berbeda seperti di atas. Tema materi tersbut yaitu: Resistor Pembagi Tegangan, Pengukuran Dasar Listrik, Hukum
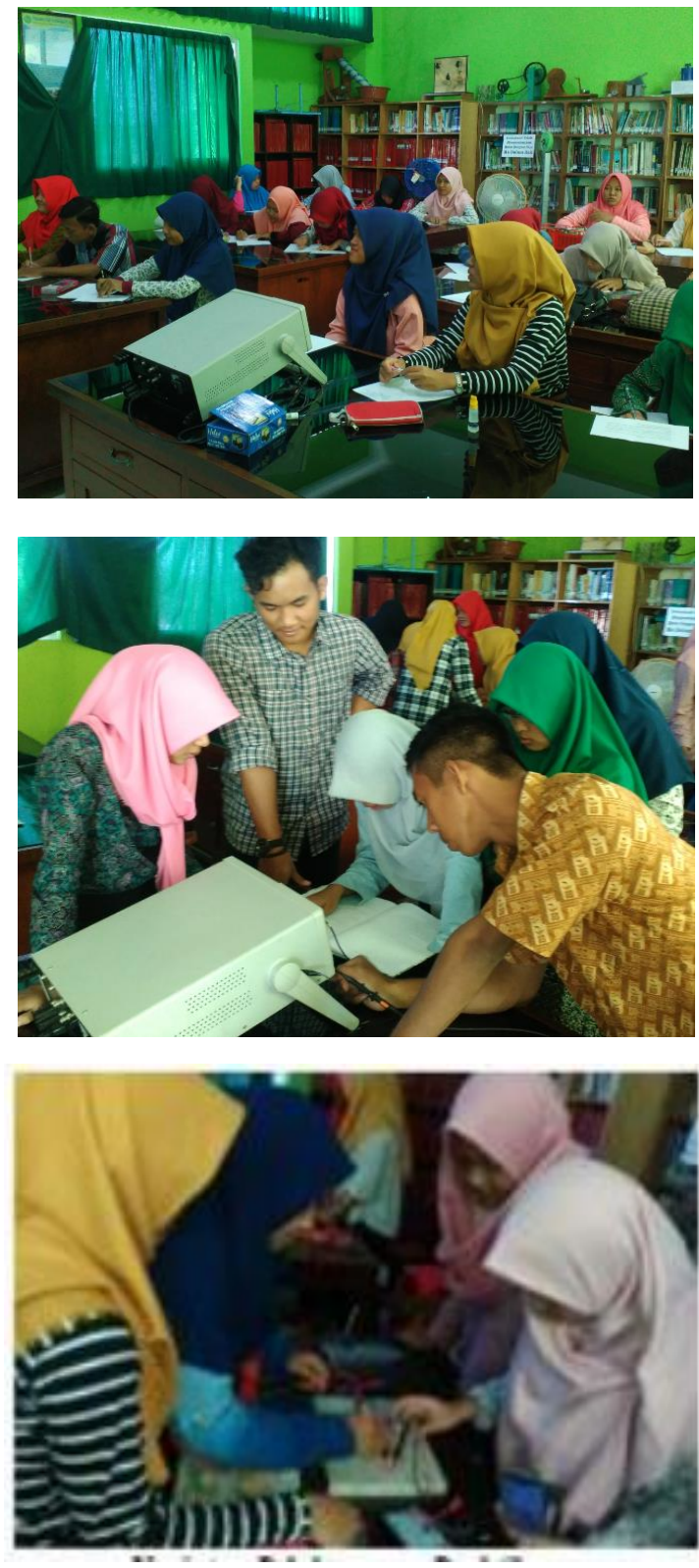

a
Kirchoff, Menentukan Indeks Bias pada Kaca Plan Paralel, dan Osiloskop. Kelima materi tersebut dilakukan dengan "Humanistik" yang artinya mahasiswa dapat memilih sendiri materi yang akan dipraktekkan atau diujicobakan, sehingga mereka tahu akan kemampuan diri mereka sendiri dalam menghadapi kesulitan dan mampu menyelesaikan permasalahan yang dihadapinya..
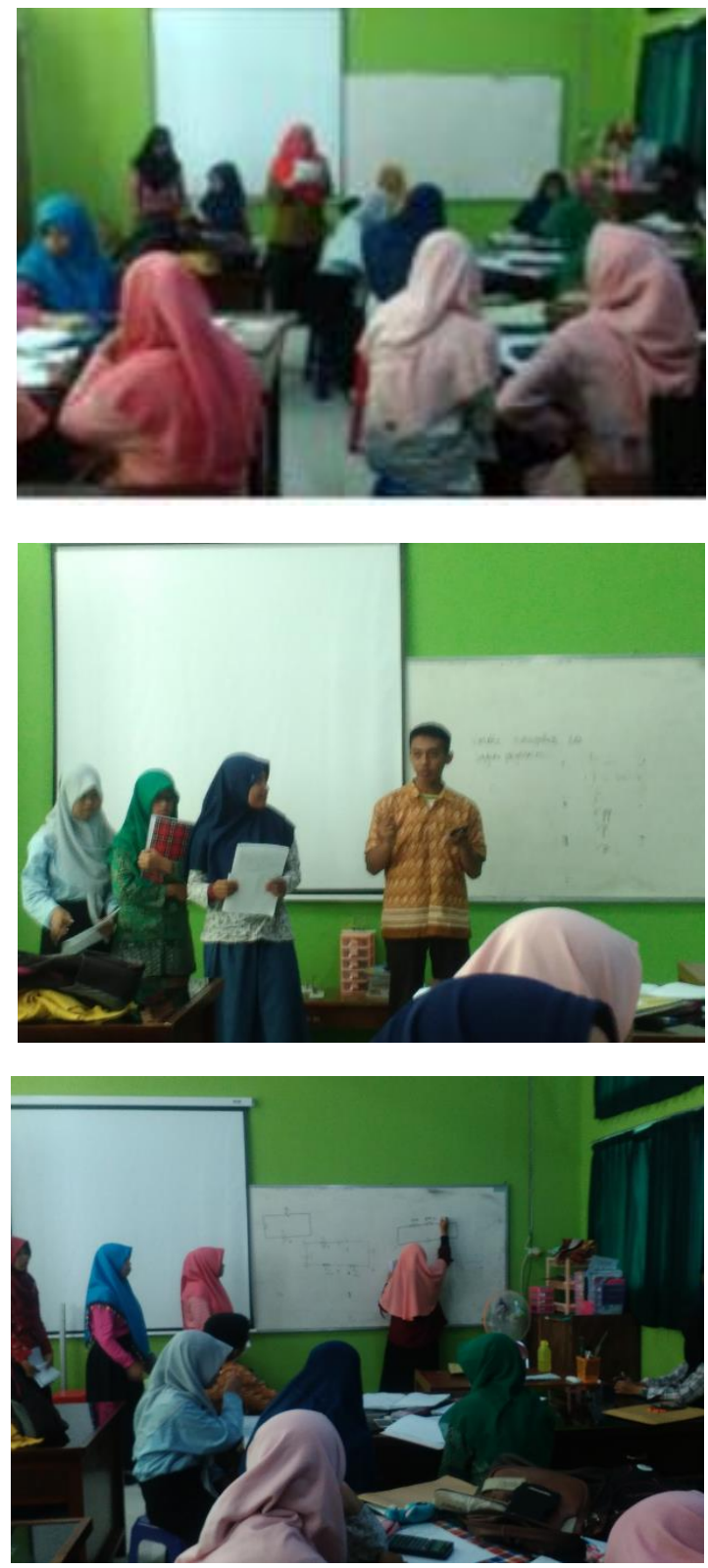

b

Gambar 1. Pelaksanaan Pre test dan Praktikum (a) dan Presentasi Hasil Diskusi Masing-Masing Kelompok

Penelitian yang telah dilakukan oleh kelanjutan penelitian ini, yaitu data yang Pratiwi dan Nurhidayati (2017) menghasilkan menggambarkan tingkat kemampuan mahasiswa berbagai data yang diperlukan dalam analisis baik dalam penguasaan materi maupun dalam 
kemampuan berpikir tingat tinggi (HOT) pada level I. Sebelum dilakukan proses analisis maka dilakukan uji normalitas data untuk menentukan distribusi kenormalan data yang diperoleh dari hasil penelitian. Uji normalitas menggunakan uji Kolmogorov Smirnov antara data uji variabel $X$ dan $\mathrm{Y}$ dengan mengambil nilai signifikansi sebesar $5 \%$. Dalam uji ini jika nilai signifikan sinya di atas 0,05 maka data dikatakan terdistribusi normal dan akan sebaliknya. Hasil pengujian uji normalitas menghasilkan nilai signifikan sebesar 0,994 (pada SPSS ditunjuk kan pada nilai asymp. Sig 2-tailed), artinya nilai signifikansi di atas 0,05 sehingga dikatakan terdistribusi normal. Berikut ini dokumentasi saat pelaksanaan praktikum pada Gambar 1 .

Hasil uji korelasi juga menunjukkan nilai korelasi yang cukup kecil hanya sebesar 0,307. Nilai korelasi yang cukup kecil ini ditunjukkan dengan adanaya kenaikan yang kecil sebesar 5 $\%$ saja. Penilaian Implementasi model POE inkuiri dengan cara observasi ketika praktikum berlangsung dan ketika mahasiswa melakukan presentasi proses pelaksanaan praktikum. Selain itu juga melalui penilaian kemampuan maha siswa dalam membuat hipotesis yang tertuang dalam soal HOT dan laporan praktikum (posttest) seperti ditunjukkan pada Tabel 2 Implementasi model POE inkuiri yang memiliki pengaruh dan korelasi yang kecil ini disebabkan karena dalam hal ini digunakan dalam pem belajaran praktikum dimana mahasiswa belajar mandiri melalui modul atau petunjuk praktikum secara mandiri baik dari arahan asisten ataupun dosen.

Hasil penelitian ini menunjukkan masih banyak potensi penelitian dan eksperimen lebih lanjut untuk menganalisis kemampuan berpikir tingkat tinggi mahasiswa dalam menyelesaikan permasalahan. Penelitian yang dilakukan yang hanya berfokus pada kemampuan berpikir tingkat tinggi level I pada tahap decision making. Tahap ini sangat penting sebagai kemampuan lanjutan dalam kemampuan maha siswa mengkonsep permasalahan yang dihadapi sebelum dapat diselesaikan dan menerapkan solusi yang telah dipilih sesuai kondisi yang ada.
Tabel 2. Rekapitulasi Nilai Variabel $X$ dan $Y$

\begin{tabular}{ccc}
\hline \hline Kode & $\begin{array}{c}\text { Model POE } \\
\text { Inquiri-Humanistik }\end{array}$ & $\begin{array}{c}\text { HOT } \\
\text { Decision Making }\end{array}$ \\
\hline \hline 1 & 71 & 60 \\
2 & 75 & 75 \\
3 & 79 & 90 \\
4 & 79 & 75 \\
5 & 83 & 90 \\
6 & 83 & 60 \\
7 & 79 & 60 \\
8 & 71 & 60 \\
9 & 87 & 60 \\
10 & 75 & 60 \\
11 & 71 & 60 \\
12 & 79 & 75 \\
13 & 63 & 45 \\
14 & 71 & 60 \\
15 & 59 & 60 \\
16 & 75 & 75 \\
17 & 79 & 45 \\
18 & 83 & 45 \\
19 & 79 & 60 \\
20 & 83 & 90 \\
\hline \hline Jml & 1524,7 & $\mathbf{6 5}, 25$ \\
\hline Rata2 & 76 & \\
\hline \hline & & \\
\hline
\end{tabular}

Catatan: Nilai HOT Level I pada tahap II Decision Making

Tahap decision making sangat penting sebagai tahap akhir proses penyelesaian masalah. Terdapat dua indikator dalam menilai kemampuan ini, yaitu kemampuan menjelaskan tujuan proyek dan dapat memilih solusi dari sekian banyak alternatif solusi sesuai per masalahan yang ada.

Tabel 2 dan Tabel 3 menunjukkan per bandingan kemampuan HOT Level I dan HOT Level I hanya pada tahap II Decision Making. Dibandingkan dengan nilai kemampuan awal mahasiswa kemampuan HOT secara keseluruh an pada level I cukup rendah hanya rata-rata 58, sedangkan pada tahap II nya saja mengalami kenaikan menjadi 62,25. Hal ini memperlihatkan bahwa kemampuan HOT Level I sebagai level tertinggi masih cukup rendah. Hal ini terjadi karena mahasiswa belum terbiasa mengerjakan atau meyelesaikan permasalahan bersifat analisis. Disamping itu mahasiswa juga merupa kan mahasiswa semester III sebagai mahasiswa pemula peralihan dari masa SMU. 
Tabel 3. Rekapitulasi Hasil Pre Test, Implementasi POE Inkuiri, Kemampu an HOT dan Post Test Per Mahasiswa

\begin{tabular}{ccccccc}
\hline No. & $\begin{array}{c}\text { Kode } \\
\text { Mhs }\end{array}$ & Pre Test & $\begin{array}{c}\text { POE- } \\
\text { Inkuiri }\end{array}$ & HOT & $\begin{array}{c}\text { Post } \\
\text { Test }\end{array}$ & Rata2 \\
\hline \hline 1 & P1 & 60 & 71 & 47 & 83 & 65 \\
2 & P2 & 78 & 75 & 59 & 80 & 73 \\
3 & P3 & 78 & 79 & 59 & 83 & 75 \\
4 & P4 & 78 & 79 & 63 & 80 & 75 \\
5 & P5 & 95 & 83 & 71 & 83 & 83 \\
6 & P6 & 72 & 83 & 59 & 81 & 74 \\
7 & P7 & 78 & 79 & 63 & 80 & 75 \\
8 & P8 & 72 & 71 & 55 & 80 & 70 \\
9 & P9 & 78 & 87 & 59 & 80 & 76 \\
10 & P10 & 72 & 75 & 51 & 82 & 70 \\
11 & P11 & 66 & 71 & 63 & 80 & 70 \\
12 & P12 & 84 & 79 & 63 & 82 & 77 \\
13 & P13 & 60 & 63 & 51 & 77 & 63 \\
14 & P14 & 78 & 71 & 59 & 77 & 71 \\
15 & P15 & 72 & 59 & 51 & 75 & 64 \\
16 & P16 & 78 & 75 & 67 & 82 & 76 \\
17 & P17 & 54 & 79 & 43 & 79 & 64 \\
18 & P18 & 72 & 83 & 51 & 79 & 71 \\
19 & P19 & 78 & 79 & 55 & 82 & 74 \\
20 & P20 & 90 & 83 & 71 & 80 & 81 \\
\hline \hline Rata-Rata & 75 & 76 & $\mathbf{5 8}$ & $\mathbf{8 0}$ & $\mathbf{7 2}$ \\
\hline
\end{tabular}

Catatan : Nilai HOT untuk semua Level I

Hasil perhitungan kemampuan berpikir tingkat tinggi menunjukkan rata-rata perolehan nilai sebesar 62,25 lebih besar 7\% dari perolehan nilai total semua indikator. Nilai tertinggi diperoleh sebesar 90 dan nilai terendah sebesar 60. Hal ini menunjukkan menghasilkan penilaian yang cukup signifakan dalam ke mampuan HOT secara umum. Berikut ini tabel perolehan nilai POE dan HOT tahap decision making dapat dilihat pada Tabel 2.

Hasil ini belum menunjukkan hasil yang signifikan, karena banyak faktor penghambat dan kendala dalam proses pelaksanaannya, yaitu:

1. Model POE perlu dibandingkan pe nerapannya dalam matakuliah teori bukan hanya praktik,

2. Awal pelaksanaan pembelajaran maha siswa kurang penjelasan sebelum pelakanaan,

3. Perlu dibuat model terintegrasi sesuai dengan model pembelajaran yang dilaku kan,

4. Peralatan praktikum yang kurang me madai,

5. Kurangnya persiapan mahasiswa dalam pelaksanaan pembelajaran,
6. Mahasiswa belum terbiasa dengan soalsoal aplikasi HOT yang memerlukan pemikiran analisis.

Diharapkan dengan adanya solusi terbaru dapat mengatasi kendala dan problematika yang dihadapi dalam penelitian ini.

\section{KESIMPULAN} brikut:

Kesimpulan dalam penelitian ini sebagai

a. Studi analisis implementasi model POE berbasis inquiri-humanistik untuk meningkat kan kemampuan HOT Level I pada tahap decision making pada matakuliah praktikum fisika dasar dilakukan dengan tes sebelum dan sesudah pembelajaran. Sedangkan proses pengambilan data untuk mengetahui implementasi model POE digunakan observasi dan untuk mengetahui kemampuan HOT level I menggunakan soal tes HOT.

b. Implementasi model POE berbasis inquirihumanistik dapat meningkatkan kemampuan HOT level I sebesar $5 \%$ dari nilai semula. Kemampuan ini ditunjukan dari hasil tes sebelum pembelajaran sebesar 75 menjadi 80 tes sesudah pembelajaran.

c. Hasil uji coba statistik uji korelasi antara implementasi model POE berbasis inquirihumanistik sebesar 0,307 dengan kenaikan $5 \%$ dari nilai sebelum dan sesudah pembelajaran.

\section{DAFTAR PUSTAKA}

Azwar, Saiffudin. 2012. Metode Penelitian. Pustaka Pelajar, Yogyakarta.

Indrawati, dan W. Setiawan. 2009. Pembelajaran Aktif, Kreatif, Efektif, dan Menyenangkan untuk Guru SD. PPPPTK IPA, Bandung.

Mundir. 2013. Statistik Pendidika.Pustaka Pelajar., Yogyakarta.

Muzari, I, Ashadi dan Prayitno, B, A. 2016. Pengembangan Modul IPA Terpadu Berbasis SETS Pada Tema Makanan Sehat dan Tubuhku untuk Meningkatkan Hasil Belajar. Jurnal Inkuiri, Vol. 5, No. 1,21-27.

Passey, Don. 2009. Higher Order Thinking Skils: An Exploration of Aspects of Learning and Thinking and How ICT can be Used to Support these processes. Department of Educational Research Lancester University. 
Pratiwi, Umi dan Nurhidayati. 2016. Studi Analisis Implementasi Model POE Berbasis Inquiri-Humanistik untuk Meningkatkan Higher Order Thinkng Skill (Hot Skil) Level I pada Praktikum Fisika Dasar. Prosiding Urecol 6. Vol. 1.

Pratiwi, Umi dan Fasha, Eka Farida. 2015. Pengembangan Instrumen Penilaian HOTS Berbasis Kurikulum 2013 Terhadap Sikap Disiplin. Jurnal JPPI UNTIRTA Banten, Vol. 1(1):123-142.
Prayitno, Dwi. 2009. Mandiri Belajar SPSS. PT Buku Kita, Yogyakarta.

Sudirman. 2012. Cara Menghitung Kriteria Obyektif (Hasil Ukur). http:/Sudirmanfmump.blogspot.com/2012/0 3/cara-menghutung-kriteria-obyektifhasil.html. $\quad 30$ Maret 2012.

Sugiyono.2009. Metode Penelitia Pendidikan Pendekatan Kuantitatif, Kualitatif, dan R\&D. Penerbit Alfabeta, Bandung. 